\title{
Air Quality Monitoring in Metropolitan Harare, Zimbabwe
}

\section{Mujuru $\mathrm{M}^{1 *}$, McCrindle $\mathrm{RI}^{2}$, Gurira $\mathrm{RC}^{3}$, Zvinowanda $\mathrm{CM}^{1}$ and Maree $\mathrm{J}^{1}$}

${ }^{1}$ Tshwane University of Technology, Department of Environmental, Water and Earth Sciences, Arcadia Campus, P. O. Box 56208, Arcadia 0007, Pretoria, South Africa

${ }^{2}$ Tshwane University of Technology, Department of Chemistry, Arcadia Campus, P. O. Box 56208, Arcadia 0007, Pretoria, South Africa

${ }^{3}$ University of Zimbabwe, Department of Chemistry, P.O. Box MP 167, Mt Pleasant, Harare, Zimbabwe

\begin{abstract}
Recent studies have linked air pollution in cities to chronic health problems like cardiovascular and cardio-respiratory deaths in the population. Pollution of the atmosphere in Harare, the capital of Zimbabwe, is a source of concern. In this study four pollutants $\left(\mathrm{SO}_{2}, \mathrm{NO}_{2}, \mathrm{~Pb}\right.$, and total suspended particulate matter (TSPM)) were monitored at eight different sites scattered throughout the city for three months (July, August and September). $\mathrm{SO}_{2}$ was determined by bubbling the air into a solution of $\mathrm{H}_{2} \mathrm{O}_{2}$, followed by titration. The highest $\mathrm{SO}_{2}$ pollution of $820.0 \mu \mathrm{gg} / \mathrm{m}^{3}$ was in an industrial area and the lowest pollution of $5.0 \mu \mathrm{g} / \mathrm{m}^{3}$ was in the Central Business District (CBD). $\mathrm{SO}_{2}$ pollution was generally above the World Health Organization (WHO) 24-hour guideline value of $125 \mu \mathrm{g} / \mathrm{m}^{3}$. NO was sampled from the air by passive samplers followed by spectrophotometric determination. The highest $\mathrm{NO}_{2}$ pollution was $46.14 \mu \mathrm{g} / \mathrm{m}^{3}$ at a site with a busy road nearby and the lowest was $11.09 \mu \mathrm{g} / \mathrm{m}^{3}$ in a high population residential area. $\mathrm{NO}_{2}$ pollution was generally lower than the WHO guideline value of $40.0 \mu \mathrm{g} / \mathrm{m}^{3}$ (annual mean). The total suspended particulate matter (TSPM) was determined as "black smoke" using the Soiling Index method. The highest total suspended particulate matter was $154.31 \mu \mathrm{g} / \mathrm{m}^{3}$ found in a high population density suburb located near some industries and lowest was $9.54 \mu \mathrm{g} / \mathrm{m}^{3}$ in a low density residential area which is far from pollution sources. Lead was determined by Graphite Furnace Atomic Absorption Spectrometry (GFAAS) for each month for every site and ranged from 0.01 to $0.72 \mu \mathrm{g} / \mathrm{m}^{3}$. The level of $\mathrm{Pb}$ pollution was highest in July and lowest in September at all sampling sites. A positive correlation was found between the levels of $\mathrm{Pb}$ and TSPM.
\end{abstract}

Keywords: Air pollution; Pollutants; Sulphur dioxide; Nitrogen dioxide; Particulate matter; Lead; Soiling index; Passive sampling

\section{Introduction}

Zimbabwe has experienced a rapid expansion in the national vehicle population and also high energy demands, especially in cities like Harare. Harare is the capital of Zimbabwe and had a population of 2.5 million people in 2002 [1]. It also has a large expanding industrial base and has an estimated vehicle population of 1.2 million, which are approximately two thirds of all of vehicles in Zimbabwe. Vehicles in Harare are often not roadworthy due to lack of proper maintenance and many do not have catalytic converters $[1,2]$.

Another contribution to air pollution in Harare comes from the use of old technology and equipment by the industries. Companies cannot replace old technologies due to the economic down-turn or do not have abatement equipment to control emissions into the atmosphere [2].

Data on air pollution in third world cities such as Harare is scanty or lacking [3-6]. A few isolated studies [6,7] on air pollution have been done in the past and there is a need for fresh data to gauge the pollution trends for the whole city of Harare. Currently, air pollution studies and measurements by local and national governments have been abandoned in Zimbabwe.

Past isolated studies $[2,4,7]$ have found the pollutants studied in the current investigation to be far above the WHO guidelines [8]. For example the level of $\mathrm{SO}_{2}$ at Mt. Hampden, a residential area in Harare, was found to be $289 \mu \mathrm{g} / \mathrm{m}^{3}$ in 1989 , which is 5.4 times higher than the WHO guidelines. During the same study period, dust particles were found to be $60-90 \mu \mathrm{g} / \mathrm{m}^{3}$, which is 7-9 times higher than the WHO guidelines [6,7].

The health impact of toxic pollutants (metals like $\mathrm{Pb}$ and gases like $\mathrm{SO}_{2}$ and $\mathrm{NO}_{2}$ ) emitted into the atmosphere has gained attention from governments and the scientific community over the last two decades. Knowledge of the identity, ambient concentrations and fate of these pollutants is of prime concern as it is well known that high pollution levels in the air may have negative effects on plants, animals and the exposed human population [9-12].

$\mathrm{NO}_{x}$ in the environment also increases substances such as ozone $[13,14]$ and some toxic nitrosamines [15]. $\mathrm{NO}_{2}$, in combination with $\mathrm{SO}_{2}$, has been known to reduce the growth of plants $[13,14,16,17]$. The effects of $\mathrm{SO}_{2}$, one of the most common air pollutants, on vegetation have been extensively studied [16,17]. It has been shown to reduce root dry weight significantly and degrade photosynthetic protein content in plants [16]. Sources of $\mathrm{Pb}$ and $\mathrm{SO}_{2}$ in the air come from burning oil, coal and other fuels and industrial processes. $\mathrm{SO}_{2}$ is a water-soluble gas that is absorbed in the upper respiratory system where acidic oxides irritate the respiratory system and react with water to form acidic sulphates. Long exposure to high doses of $\mathrm{SO}_{2}$ and particulate matter has been shown to result in a higher frequency of respiratory infection among children. Studies have shown a link between air pollution and health effects like eye and respiratory irritation, asthma, chronic bronchitis and higher death rates [18-20]. Studies done in London in 1954, showed a strong link between mortalities caused by respiratory ailments and levels of smoke pollution and $\mathrm{SO}_{2}[21]$

The aim of this study was to update the data on levels of $\mathrm{SO}_{2}, \mathrm{NO}_{2}$

*Corresponding author: Mujuru M, Tshwane University of Technology, Department of Environmental, Water and Earth Sciences, Arcadia Campus, P. O. Box 56208 Arcadia 0007, Pretoria, South Africa, E-mail: mujurum@tut.ac.za

Received February 15, 2012; Accepted March 14, 2012; Published March 16 , 2012

Citation: Mujuru M, McCrindle RI, Gurira RC, Zvinowanda CM, Maree J (2012) Air Quality Monitoring in Metropolitan Harare, Zimbabwe. J Environment Analytic Toxicol 2:131. doi:10.4172/2161-0525.1000131

Copyright: ( 2012 Mujuru M, et al. This is an open-access article distributed unde the terms of the Creative Commons Attribution License, which permits unrestricted use, distribution, and reproduction in any medium, provided the original author and source are credited. 
and TSPM and determine $\mathrm{Pb}$ which has not been measured before in the ambient air of Harare, Zimbabwe. These pollutants were also determined on a more sites scattered throughout the city of Harare, unlike the previous studies which were single site studies.

\section{Experimental}

\section{Sampling}

Sampling was done from eight sites in Harare at a frequency of 3 times a week. Some of the sites were located in high pollution areas with high industrial activities, while others were located in areas far away from pollution sources. These sites are identified and described in Table 1 and Figure 1 below.

All the sampling sites in Harare were located at the City Health Department Clinics for security reasons (Figure 1).

Analytical procedure for determination of $\mathrm{NO}_{2}$ : The concentration of $\mathrm{NO}_{2}$ was determined using a passive sampling method. Badge-type samplers by Krochmal and Gorski [22] (Centrum - Wdrozeniowe "Polycomp", Cracow, Poland), were used. They had an internal diameter of $25 \mathrm{~mm}$ and depth of $10 \mathrm{~mm}$. All parts of the passive sampler are re-usable with the exception of the filter paper.

Filter papers (Whatman 42) were impregnated with $0.1 \mathrm{ml}$ of $20 \%$ $(\mathrm{m} / \mathrm{m})$ triethanolamine (TEA) solution to absorb the $\mathrm{NO}_{2}$. Saltzman Solution was then used to wash the filter paper and absorbance measured at $540 \mathrm{~nm}$ with UV-Vis (Pharmacia Biotech, Ultraspec, (Cambridge, UK)).

The reagents used were analytical grade (purchased from Saarchem, Gauteng, South Africa) and Millipore water was used for preparation of all solutions.

Samplers were marked with a water-proof marker indicating the sites identified in Table 1. At least 5 samplers were left as blanks and were kept in air- tight containers.

At the sampling site the samplers were attached to holders, the caps removed and the samplers hung 1.5-2 $\mathrm{m}$ above the ground. At least 3 samplers were placed at each sampling site several meters from each other. The times of exposure of the samplers were recorded in a $\log$ book. During exposure the average temperatures of ambient air were also recorded.

After the samplers had been exposed at the sampling sites for determined periods, the samples were collected and taken to the laboratory for $\mathrm{NO}_{2}$ determination. Analyses for $\mathrm{NO}_{2}$ absorbed as nitrite were done spectrophotometrically after reaction with Saltzman [23].

The sampling periods varied from 24 hours to 7 days and the samplers were placed in open areas to obtain maximum exposure to ambient air flow.

Calculation of the final result, after spectrophotometric determination, was done using the following formula [24,25]:

$$
\mathrm{X}=(\operatorname{mx} 144000) /(\mathrm{Pxt})
$$

Where: $\mathrm{X}$ is the concentration of $\mathrm{NO}_{2} ; \mathrm{m}$ is the mass of nitrite in $\mu \mathrm{g}$ which was determined in the sampler; $t$ is the period of exposure and $\mathrm{P}$ is an empirical coefficient given by the manufacturer of the samplers. $\mathrm{P}$ is the mass of nitrite determined in the sampler after exposure at the concentration of $\mathrm{NO}_{2}$ of $100 \mu \mathrm{g} / \mathrm{m}^{3}$.

The dimension of $\mathrm{P}$ is: $\left(\mu \mathrm{g} \mathrm{NO}_{2}^{-}\right) /\left(1440 \mathrm{~min} \times 100 \mu \mathrm{g} / \mathrm{m}^{3}\left(\mathrm{NO}_{2}\right)\right)(2)$ For the samplers used in this study the value of the coefficient $\mathrm{P}$ at temperature $10^{\circ} \mathrm{C}$ was 2.23 units. For temperatures different from $10^{\circ} \mathrm{C}$, a correction of the coefficient $\mathrm{P}$ should be done [24]:

$$
\mathrm{P}=1.96+0.027 \times \mathrm{T}
$$

where $\mathrm{T}$ is the temperature in ${ }^{\circ} \mathrm{C}$. The final result for the determination of $\mathrm{NO}_{2}$ at each sampling site was the mean of the three results obtained from simultaneously exposed samplers.

Determination of $\mathrm{SO}_{2}$ in ambient air: The Bubbler Method $[24,26]$ was used for the determination of $\mathrm{SO}_{2}$. The method is based on the reaction:

$$
\mathrm{SO}_{2(\mathrm{~g})}+\mathrm{H}_{2} \mathrm{O}_{2(\mathrm{aq})} \rightarrow \mathrm{H}_{2} \mathrm{SO}_{4(\mathrm{aq})}
$$

The apparatus used was designed by the National Physical Research Laboratory of UK. It was assembled and installed at each of the sites in Table 1.

$\mathrm{H}_{2} \mathrm{O}_{2}$ solution and filter papers were changed in the mornings on Mondays, Wednesdays and Fridays, these being sampling periods of 48, 48 and 72 hours respectively. The air volumes which were drawn during the 48 hour period were 1.4 to $1.7 \mathrm{~m}^{3}$ and for 72 hours were 2.2 to $2.5 \mathrm{~m}^{3}$.

The $\mathrm{SO}_{2}$ concentrations were expressed in $\mu \mathrm{g} / \mathrm{m}^{3}$ of air sampled. When using sodium borate or sulphuric acid, the quantity of $\mathrm{SO}_{2}$ in

\begin{tabular}{|c|c|}
\hline SITE & SITE DESCRIPTION \\
\hline Town House & $\begin{array}{l}\text { This is in Harare city centre. The sources of gas pollution are predominantly vehicle emissions. There are two busy roadways, L. Takawira and J. } \\
\text { Nyerere way on either side. It is located in a triangular piece of land. }\end{array}$ \\
\hline Southerton & $\begin{array}{l}\text { This is located in a residential area which is surrounded by industries and is about } 7 \mathrm{~km} \text { southwest of the city. Winds transport pollutants from } \\
\text { Southerton and Mbare industrial areas to this sampling site. }\end{array}$ \\
\hline Mbare & $\begin{array}{l}\text { It is residential area about } 4 \mathrm{~km} \text { south from the city centre. The source of pollution is Graniteside, an industrial area, and the open burning of urban } \\
\text { refuse that is done in the vicinity. There is a major terminus for buses to all parts of Harare and the whole of Zimbabwe near the sampling site. }\end{array}$ \\
\hline Hatfield & This is a residential area about $8 \mathrm{~km}$ south-east of the city centre and $4 \mathrm{~km}$ north of a major airport. \\
\hline Highfields & $\begin{array}{l}\text { This is a residential area about } 9 \mathrm{~km} \text { south-west of city centre and south of Willowvale industries and south-west of Southerton industrial areas. It is } \\
\text { subject to pollution from these areas. }\end{array}$ \\
\hline $\begin{array}{l}\text { Beatrice Road } \\
\text { Hospital }\end{array}$ & $\begin{array}{l}\text { Beatrice Road Hospital is along a main road Simon Mazorodze that separate Southerton industries and Mbare residential area. Pollution is mainly } \\
\text { from Southerton industries. }\end{array}$ \\
\hline Mabelreign & This is a low density residential $8 \mathrm{~km}$ northwest of the city centre. There are no nearby pollution sources. \\
\hline Mufakose & $\begin{array}{l}\text { This is a high population density suburb located southwest of Harare, about } 14 \mathrm{~km} \text { from the city centre and } 2-3 \mathrm{~km} \text { west of Aspindale industries, } \\
\text { which include a major fertilizer manufacturer. }\end{array}$ \\
\hline
\end{tabular}
the sample was determined by formula ( $128 \mathrm{M} \mu \mathrm{g}$, where $\mathrm{M}$ is the net volume of the titrant in milliliters) [24].

Table 1: Air Sampling Sites in Harare. 


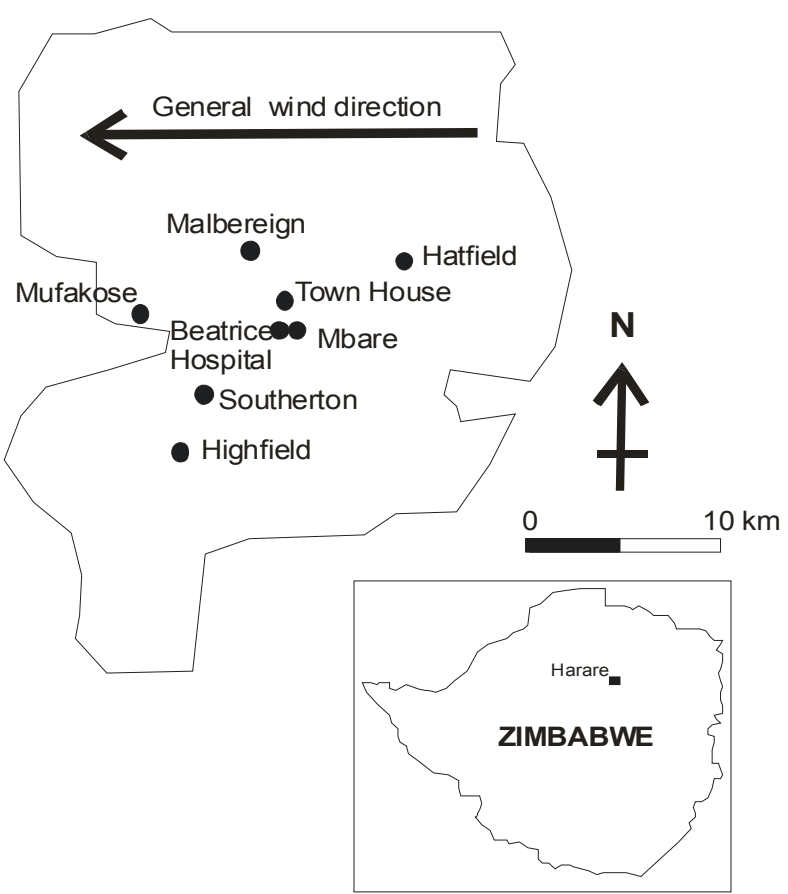

Figure 1: Location of the Eight Sampling Sites in Harare.

The concentration of sulphur dioxide was given by [24]:

$$
\mathrm{C}=(128 \times \mathrm{M} / \mathrm{V}) \mu \mathrm{g} / \mathrm{m}^{3}
$$

where $\mathrm{V}$ was the volume of the air which was sampled in $\mathrm{m}^{3}$.

Determination of total suspended particulate matter (TSPM): The British Standard technique for monitoring fine suspended particulate matter as "black smoke", is well established [24], and was used in this study. The apparatus used was that described for the determination of $\mathrm{SO}_{2}$ [24]. A measured volume of air was drawn at a constant and measured flow rate through a paper filter whose light transmission had been previously measured. Suspended particulate matter was collected on the filter, forming a dark stain. A densitometer was used to measure the darkness of the stain, and this measurement was then used to calculate the concentration of particulate matter in the sampled air. The difference in light transmission between a clean and exposed paper gave the Soling Index $\left(\mathrm{S} / \mathrm{m}^{3}\right)$. Conversion tables use a factor to convert the Soiling Index to mass $\mathrm{m}^{-3}$ [24].

The densitometer was designed by the National Physical Research Laboratory in the UK. It consisted of a barrier-layer photocell, a microammeter (with low internal resistance) and a $12 \mathrm{~V}$ light source. The meter (ad a linear scale marked from 0 to $1005 \mathrm{~A}$, which gave the percentage light transmission directly. A voltage stabilizer giving $12 \mathrm{~V}$ d.c. was used as the light source. A Whatman 42 filter paper with a 20 $\%$ light absorption was used as reference filter.

Determination of $\mathbf{P b}$ in particulate matter: All the filter papers from each sampling site which were used to determine TSPM for each month were washed together with ultra pure water and the $\mathrm{Pb}$ in the water was determined using GF-AAS (Shimadzu AA-6800, Kyoto, Japan). The calibration curve was prepared by injecting aqueous $\mathrm{Pb}$ standard solutions $(10 \mu \mathrm{l})$ into the instrument. The samples were also injected similarly. The instrument heating program for $\mathrm{Pb}$ was used. The detection limit was $2 \mathrm{ppb}$.

\section{Results and Discussion}

\section{Sulphur dioxide}

For $\mathrm{SO}_{2}$ the order of pollution for the monthly average is shown in Figure 2. Southerton was the highest and Town House the lowest.

This order was generally observed for the three months of this study. It can be observed that the month of July had the highest $\mathrm{SO}_{2}$ concentrations and September had the least (Figure 2).

The pollution for $48 \mathrm{~h}$ sampling periods for Southerton for August and September showed that August pollution was higher than that of September for most of the sampling periods (Figure 3). For Town House which had the lowest $\mathrm{SO}_{2}$ pollution relative to all sampling sites, the pollution did not follow any particular trend (Figure 4).

$\mathrm{SO}_{2}$ pollution for August was also higher than that of September for all the other sampling periods (Table 2).

For Southerton (see also Figure 3 ) these results were expected because it is surrounded by many industrial sites as well as Harare Hospital, which burns a lot of coal. Most of the factories around the sampling site use fired coal boilers. Zimbabwean coal is known to contain $2-3 \%$ sulphur [25]. Coupled with $\mathrm{SO}_{2}$ emission from industries are the emissions from vehicles in the area, in particular diesel vehicles.

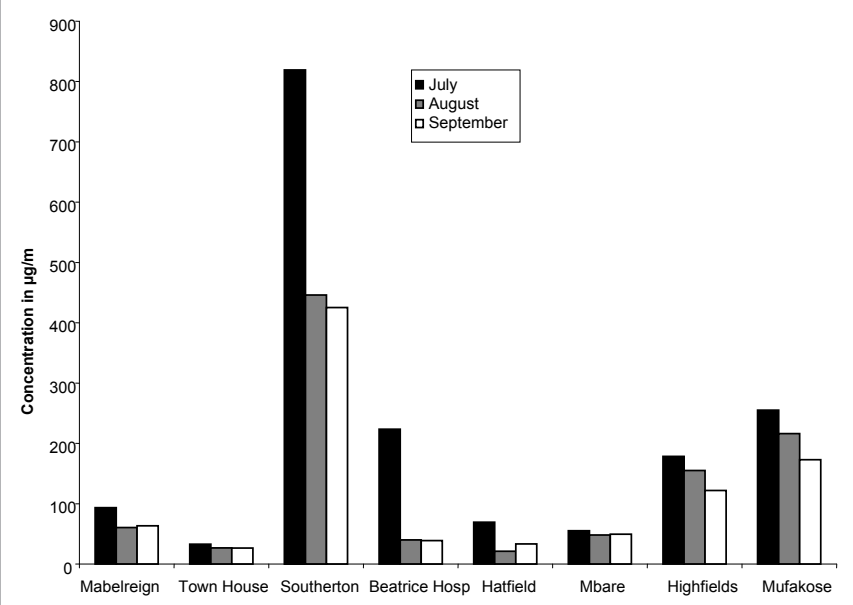

Figure 2: Monthly average concentration of $\mathrm{SO}_{2}$ in $\mu \mathrm{g} / \mathrm{m}^{3}$.

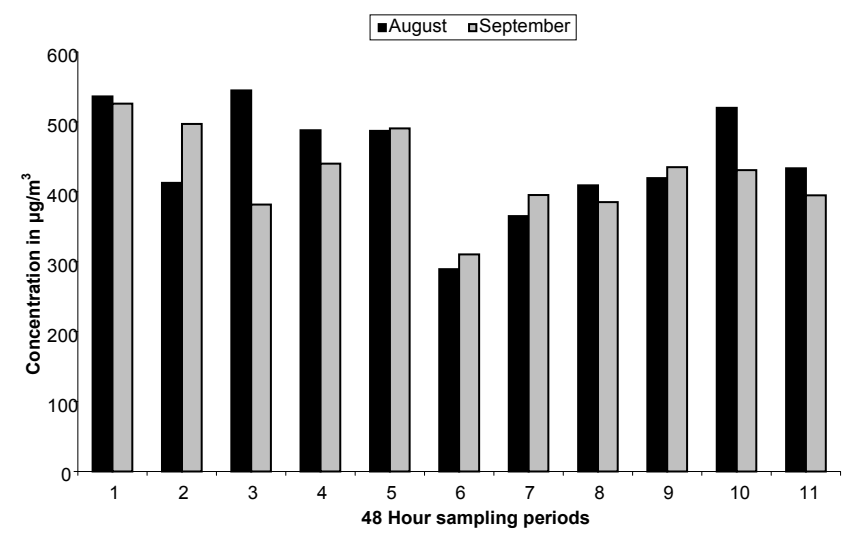

Figure 3: $\mathrm{SO}_{2}$ Levels in Southerton for August and September. 
Figures 3 and 4 shows $\mathrm{SO}_{2}$ levels of Southerton which has the highest ambient concentrations and Town House which has the lowest concentrations, respectively. Town House is at the centre of the CBD and there are no industries which can pollute the ambient air with $\mathrm{SO}_{2}$, only vehicular and transported pollution.

The $\mathrm{SO}_{2}$ concentrations of the other sampling sites are tabulated in Table 2 below:

For all the sampling sites, except Hatfield, the concentration of $\mathrm{SO}_{2}$ was above the WHO 24-hour mean guideline value of $125 \mu \mathrm{g} / \mathrm{m}^{3}$ (Table 2). Some of these sampling sites like Southerton, Mbare and Beatrice Road Hospital are affected by industrial pollution. One nearby polluter is the thermal power station supplying electricity to the city of Harare which burns coal throughout for $24 \mathrm{~h}$. Since these sampling sites were near residential areas, the pollution may result in health problems. Epidemiological studies indicate adverse public health effects, like childhood respiratory disease and all-age mortality are prevalent with excess $\mathrm{SO}_{2}[21,27-30]$

For Mufakose and Hatfield the results were not expected to be as high, due to their long distances from industrial activity. However, meteorological factors may explain the observed higher than normal concentrations of $\mathrm{SO}_{2}$ at these sites. The general wind direction for Harare which is from east to west or north-westerly is shown in Figure 1. Mufakose being in the far west is affected by transported pollution from industries. Hatfield is affected by transported pollution from industries in Msasa such as a fertilizer company, where coal is used extensively for heating and burning of sulphur rocks during the manufacture of oleum. This is also the case for areas like Mabelreign which experiences north-westerly winds coming from industrial areas.
For Southerton, Mufakose and Highfields the levels of $\mathrm{SO}_{2}$ pollution were above the WHO guideline of $350-500 \mathrm{~g} / \mathrm{m}^{3}$. A study of the relationship between the levels of pollution and respiratory disease in these areas should be undertaken, since these areas have high population densities. In recent studies it has been shown that tens of thousands of premature cardiovascular deaths per year are linked to air pollution [21,27-32].

\section{Nitrogen dioxide}

The monthly average concentrations of the various sampling sites are illustrated in Figure 5.

For all the sampling sites there was an increased $\mathrm{NO}_{2}$ concentration in September compared with July. This indicates seasonal variation of $\mathrm{NO}_{2}$ levels in the ambient of Harare. July is winter while September is the onset of summer with temperatures averaging $19.8^{\circ} \mathrm{C}$, being higher than those of July (average of $17.3^{\circ} \mathrm{C}$ ). Unlike $\mathrm{SO}_{2}$, where Southerton had the highest concentrations, the highest levels of $\mathrm{NO}_{2}$ in ambient air were at Beatrice Road Hospital followed by Town House in central Harare. These two sites are in areas where there are a high number of vehicles and this may be the source of $\mathrm{NO}_{2}$. In Mufakose where there are low vehicle numbers, the $\mathrm{NO}_{2}$ concentration was lower than for other sampling sites, like Town House and Beatrice Road Hospital. Low concentrations of $\mathrm{NO}_{2}$ in Mufakose also show that $\mathrm{NO}_{2}$ is transported less than $\mathrm{SO}_{2}$.

The concentrations of $\mathrm{NO}_{2}$ for the various sites in Harare may be seen in Table 3 for sampling periods during the months of August and September.

Town House area experienced one of the highest $\mathrm{NO}_{2}$ ambient air pollution $\left(72.7 \mu \mathrm{g} / \mathrm{m}^{3}\right)$ at the beginning of the month of September. At

\begin{tabular}{|c|c|c|c|c|c|c|c|c|c|c|c|c|}
\hline \multirow{2}{*}{$\begin{array}{l}\text { Period } \\
\text { (48hrs) }\end{array}$} & \multicolumn{2}{|l|}{ Mbare } & \multicolumn{2}{|l|}{ Highfields } & \multicolumn{2}{|l|}{ Mufakose } & \multicolumn{2}{|c|}{ Mabelreign } & \multicolumn{2}{|c|}{ Beatrice Hosp. } & \multicolumn{2}{|l|}{ Hatfield } \\
\hline & August & Sept & August & Sept & August & Sept & August & Sept & August & Sept & August & Sept \\
\hline 1 & 61.1 & 88.4 & 206 & 224 & 292 & 179 & 70.3 & 77.0 & 536.4 & 526 & 14.4 & 56.6 \\
\hline 2 & 51.3 & 69.7 & 155 & 193 & 216 & 183 & 50.3 & 80.3 & 412.9 & 497 & 10.9 & 56.9 \\
\hline 3 & 55.2 & 50.8 & 171 & 116 & 280 & 172 & 71.6 & 56.2 & 545.1 & 381.7 & 21.9 & 31.1 \\
\hline 4 & 55.0 & 46.3 & 173 & 103 & 291 & 187 & 66.6 & 56.3 & 487.9 & 440.2 & 21.6 & 11.3 \\
\hline 5 & 38.5 & 43.3 & 139 & 126 & 277 & 199 & 61.8 & 72.2 & 487.0 & 490.4 & 23.8 & 23.9 \\
\hline 6 & 31.2 & 42.8 & 112 & 88.3 & 140 & 127 & 54.3 & 51.0 & 289.5 & 310.5 & 37.3 & 35.4 \\
\hline 7 & 41.9 & 44.1 & 118 & 94.3 & 172 & 172 & 44.7 & 60.7 & 365.2 & 395.3 & 21.7 & 40.0 \\
\hline 8 & 46.0 & 43.8 & 129 & 93.0 & 136 & 176 & 50.1 & 64.8 & 409.2 & 385.3 & 17.0 & 47.4 \\
\hline 9 & 47.7 & 49.5 & 149 & 117 & 198 & 165 & 56.9 & 70.9 & 419.4 & 402.3 & 18.7 & 42.0 \\
\hline 10 & 49.7 & 32.0 & 157 & 88.7 & 221 & 166 & 59.7 & 54.6 & 520.1 & 431.1 & 22.4 & 3.20 \\
\hline 11 & 51.1 & 33.7 & 196 & 97.2 & 157 & 179 & 77.6 & 52.3 & 433.4 & 394.8 & 23.3 & 18.4 \\
\hline
\end{tabular}

Table 2: $\mathrm{SO}_{2}$ concentrations $\left(\mu \mathrm{g} / \mathrm{m}^{3}\right)$ of various sampling sites in Harare.

\begin{tabular}{|c|c|c|c|c|c|c|c|c|c|c|c|c|}
\hline \multirow{2}{*}{$\begin{array}{l}\text { Period } \\
\text { (48hrs) }\end{array}$} & \multirow{2}{*}{$\begin{array}{l}\text { Town } \\
\text { August }\end{array}$} & \multirow{2}{*}{$\begin{array}{l}\text { House } \\
\text { Sept }\end{array}$} & \multicolumn{2}{|l|}{ Highfields } & \multicolumn{2}{|l|}{ Mufakose } & \multicolumn{2}{|c|}{ Mabelreign } & \multicolumn{2}{|c|}{ Beatrice Hosp. } & \multicolumn{2}{|c|}{ Southerton } \\
\hline & & & August & Sept & August & Sept & August & Sept & August & Sept & August & Sept \\
\hline 1 & 27.3 & 72.7 & 28.1 & 63.1 & 18.5 & 46.5 & 17.5 & 50.1 & 31.4 & 57.2 & 29.5 & 55.6 \\
\hline 2 & 42.4 & 43.7 & 50.5 & 40.4 & 27.6 & 37.4 & 23.5 & 34.7 & 35.8 & 52.5 & 37.7 & 38.0 \\
\hline 3 & 36.0 & 27.5 & 43.0 & 24.4 & 27.6 & 25.0 & 21.9 & 22.5 & 30.5 & 32.0 & 38.9 & 28.6 \\
\hline 4 & 26.8 & 59.7 & 28.7 & 45.8 & 19.5 & 28.6 & 20.4 & 31.6 & 36.1 & 55.0 & 28.1 & 34.0 \\
\hline 5 & 35.9 & 60.2 & 31.8 & 49.3 & 24.6 & 31.0 & 23.6 & 34.9 & 32.1 & 89.8 & 37.7 & 41.7 \\
\hline 6 & 46.1 & 36.6 & 29.3 & 28.5 & 21.5 & 18.4 & 17.7 & 19.4 & 29.2 & 42.0 & 30.4 & 21.9 \\
\hline 7 & 27.1 & 24.4 & 32.0 & 24.1 & 26.5 & 16.0 & 24.9 & 22.3 & 29.5 & 25.8 & 28.0 & 22.6 \\
\hline 8 & 20.6 & 48.1 & 26.3 & 38.1 & 15.2 & 32.1 & 17.0 & 23.9 & 25.1 & 45.8 & 21.8 & 36.5 \\
\hline 9 & 27.2 & 40.9 & 22.6 & 47.4 & 17.0 & 17.8 & 18.0 & 19.3 & 26.6 & 38.8 & 26.1 & 46.5 \\
\hline 10 & 41.7 & 21.3 & 33.0 & 22.2 & 27.6 & 13.3 & 25.0 & 21.4 & 46.1 & 28.4 & 42.1 & 21.1 \\
\hline 11 & 19.7 & 19.2 & 16.7 & 14.8 & 13.6 & 11.1 & 14.1 & 13.0 & 15.4 & 15.6 & 16.4 & 17.7 \\
\hline
\end{tabular}

Table 3: $\mathrm{NO}_{2}$ Concentrations at various sites in Harare in $\mu \mathrm{g} / \mathrm{m}^{3}$. 
the end of September Mufakose experienced the lowest $\mathrm{NO}_{2}$ pollution $\left(11.1 \mu \mathrm{g} / \mathrm{m}^{3}\right)$ as compared to all other sampling periods during this study.

Epidemiological studies have used $\mathrm{NO}_{2}$ as a marker to indicate a cocktail of combustion related pollutants such as ultrafine particles, $\mathrm{NO}_{x}$, particulate matter and benzene [27]. The high $\mathrm{NO}_{2}$ pollution determined at sites like Town House and Beatrice Road Hospital could relate a host of other pollutants in these areas which are associated with $\mathrm{NO}_{2}$.

\section{Total particulate suspended matter (TPSM)}

The monthly average TSPM levels for all sampling sites are shown graphically in Figure 6. The month of August had the highest TSPM levels at all the sampling sites and September had the lowest, except for Beatrice Hospital. The highest TSPM were recorded at the Highfields sampling point in August and the lowest at Beatrice Road Hospital in September. Highfields is a poor residential area with a very high population density. Most roads and parking surfaces in Highfields are not tarred and this makes the area susceptible to dusty winds in August giving higher TSPM levels than other high density residential areas like Mufakose, Mbare and Beatrice Road. Hatfield is a low density residential area with most road surfaces being tarred and thus less dust

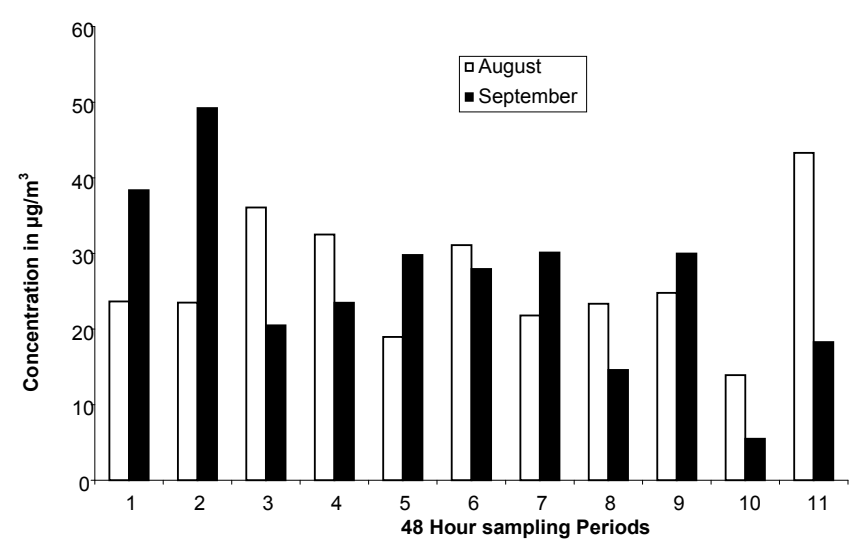

Figure 4: $\mathrm{SO}_{2}$ levels in August and September at Town House.

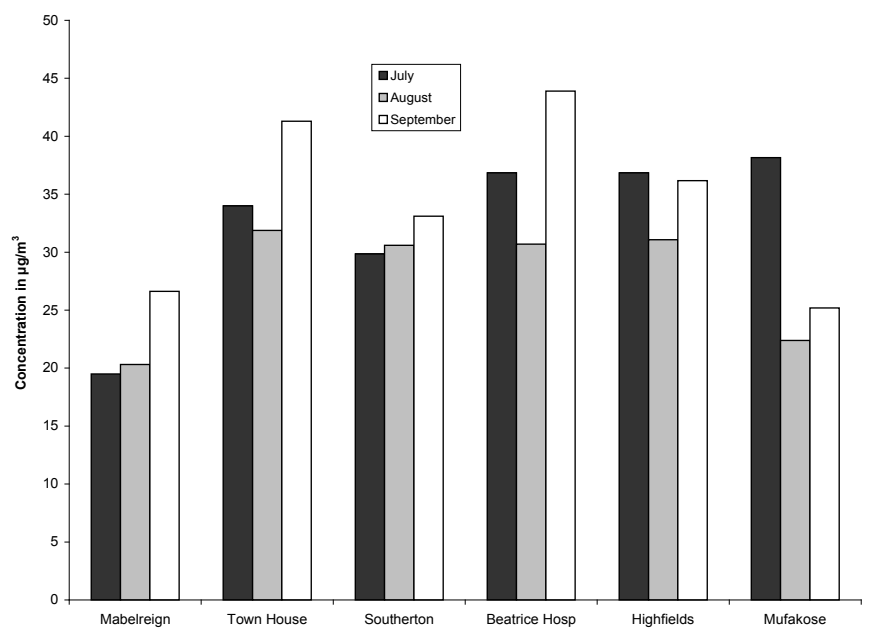

Figure 5: Average monthly $\mathrm{NO}_{2}$ concentrations.

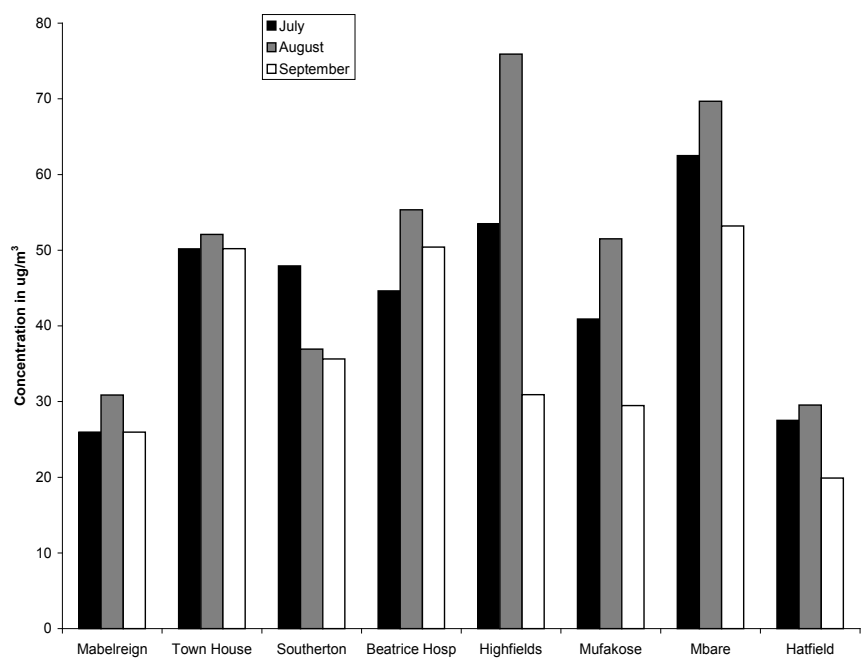

Figure 6: Average monthly TSPM levels in Harare.

results in this area. Here low TSPM levels were obtained. The month of August is the windiest month in Zimbabwe and these winds raise a variety of particulate matter from surfaces, hence the high TSPM levels determined during this month at all sites.

Table 4 gives the results of various sampling sites in Harare. During the period of this study the highest concentration of 154.3 $\mu \mathrm{g} / \mathrm{m}^{3}$ was recorded during the month of August at Highfields. The lowest concentration of $2.50 \mu \mathrm{g} / \mathrm{m}^{3}$ was obtained at the Beatrice Road sampling site.

The TSPM levels determined may not be an accurate indicator of health risks as information on particulate matter of $10 \mu \mathrm{m}$ or less $\left(\mathrm{PM}_{10}\right)$ is more useful $[33,34]$.

\section{Lead levels in harare}

The amounts of $\mathrm{Pb}$ accumulated in the TSPM filter papers in the 48 $h$ day sampling periods were below the detection limits of the GFAAS used and as a result all the filter papers for the whole month were combined to determine the monthly $\mathrm{Pb}$ average. The results are in Table 5 together with the associated TSPM monthly average concentrations.

For all the sampling sites, the month of July had the highest $\mathrm{Pb}$ and TSPM and September had the lowest. This was an indication of the seasonal variation of pollution, as July is a dry winter month while September receives some rain and has higher temperatures. The highest $\mathrm{Pb}$ level was at Highfields in July $\left(0.72 \mu \mathrm{g} / \mathrm{m}^{3}\right)$ followed by Southerton $\left(0.38 \mu \mathrm{g} / \mathrm{m}^{3}\right.$ in July). With the exception of Highfields $\left(0.72 \mu \mathrm{g} / \mathrm{m}^{3}\right)$ in July, all the values of $\mathrm{Pb}$ determined were lower than the WHO guideline of $0.5 \mu \mathrm{g} / \mathrm{m}^{3}$. Higher levels at Southerton and Highfields indicate industrial and vehicular source since there are a number of industrial concerns like a battery company in Southerton area and a high number of vehicles.

The $\mathrm{Pb}$ and TSPM levels were positively correlated statistically, with the correlation co-efficient ranging from 0.69 in July to 0.27 in September. This shows that the sources of pollution for both pollutants may be the same.

At the time of this study due to economic constraints the national and local governments had completely stopped monitoring all these pollutants and yet they could be having adverse health effects on the 


\begin{tabular}{|c|c|c|c|c|c|c|c|c|c|c|c|c|}
\hline \multirow{2}{*}{$\begin{array}{l}\text { Period } \\
48 \mathrm{Hrs}\end{array}$} & \multirow{2}{*}{$\begin{array}{l}\text { Town } \\
\text { August }\end{array}$} & \multirow{2}{*}{$\begin{array}{l}\text { House } \\
\text { Sept }\end{array}$} & \multicolumn{2}{|l|}{ Highfields } & \multicolumn{2}{|l|}{ Mufakose } & \multicolumn{2}{|c|}{ Mabelreign } & \multicolumn{2}{|c|}{ Beatrice Hosp. } & \multicolumn{2}{|c|}{ Southerton } \\
\hline & & & August & Sept & August & Sept & August & Sept & August & Sept & August & Sept \\
\hline 1 & 39.3 & 61.2 & 81.6 & 47.7 & 44.0 & 31.7 & 23.6 & 39.1 & 60.8 & 2.45 & 39.5 & 39.9 \\
\hline 2 & 62.5 & 96.8 & 56.9 & 85.5 & 66.9 & 68.9 & 26.4 & 33.6 & 10.3 & 124 & 31.0 & 65.3 \\
\hline 3 & 43.9 & 60.4 & 52.0 & 35.4 & 62.4 & 39.0 & 34.8 & 26.1 & 61.0 & 61.0 & 59.2 & 53.5 \\
\hline 4 & 74.6 & 57.4 & 104 & 6.35 & 41.3 & 9.43 & 31.7 & 9.54 & 81.5 & 83.0 & 44.1 & 23.7 \\
\hline 5 & 46.1 & 38.8 & 82.7 & 15.5 & 43.7 & 26.2 & 26.6 & 19.0 & 60.7 & 45.0 & 24.4 & 32.2 \\
\hline 6 & 37.2 & 29.7 & 33.1 & 14.5 & 21.8 & 12.8 & 13.3 & 21.7 & 39.4 & 54.3 & 12.3 & 19.0 \\
\hline 7 & 59.6 & 24.5 & 80.5 & 25.6 & 57.1 & 27.2 & 29.3 & 29.2 & 99.2 & 37.3 & 50.0 & 38.8 \\
\hline 8 & 34.2 & 79.0 & 74.9 & 42.6 & 34.7 & 42.1 & 24.7 & 38.4 & 59.5 & 74.9 & 44.6 & 38.4 \\
\hline 9 & 89.8 & 48.6 & 154 & 17.1 & 102 & 27.9 & 68.7 & 22.0 & 62.6 & 32.1 & 24.4 & 36.0 \\
\hline 10 & 49.5 & 26.6 & 64.1 & 24.1 & 53.6 & 18.6 & 27.3 & 26.3 & 43.6 & 15.4 & 39.0 & 25.5 \\
\hline 11 & 36.2 & 36.6 & 51.2 & 25.9 & 38.7 & 20.5 & 33.2 & 20.8 & 30.1 & 25.4 & 37.8 & 19.9 \\
\hline
\end{tabular}

Table 4: TPSM levels in various sites in Harare $\left(\mu \mathrm{g} / \mathrm{m}^{3}\right)$

\begin{tabular}{|c|c|c|c|c|c|c|}
\hline \multirow[b]{2}{*}{ Sampling Site } & \multicolumn{2}{|l|}{ July } & \multicolumn{2}{|l|}{ Aug } & \multicolumn{2}{|l|}{ Sep } \\
\hline & $\mathrm{Pb} / \mu \mathrm{g} / \mathrm{m}^{3}$ & $\mathrm{TSPM} / \mu \mathrm{g} / \mathrm{m}^{3}$ & $\mathrm{~Pb} / \mu \mathrm{g} / \mathrm{m}^{3}$ & $\mathrm{TSPM} / \mu \mathrm{g} / \mathrm{m}^{3}$ & $\mathrm{~Pb} / \mu \mathrm{g} / \mathrm{m}^{3}$ & $\mathrm{TSPM} / \mu \mathrm{g} / \mathrm{m}^{3}$ \\
\hline Mbare & 0.23 & 81.39 & 0.20 & 69.47 & 0.01 & 49.74 \\
\hline Highfields & 0.72 & 97.77 & 0.30 & 79.10 & 0.17 & 28.82 \\
\hline Mufakose & 0.19 & 52.58 & 0.05 & 49.85 & 0.06 & 25.08 \\
\hline Mabelreign & 0.22 & 28.82 & 0.03 & 32.97 & 0.06 & 25.55 \\
\hline Town House & 0.28 & 49.27 & 0.18 & 52.45 & 0.01 & 46.56 \\
\hline S/ton & 0.38 & 46.38 & 0.10 & 37.77 & 0.03 & 32.81 \\
\hline Beatrice & 0.27 & 38.90 & 0.14 & 56.37 & 0.04 & 42.91 \\
\hline Hatfield & 0.25 & 28.11 & 0.14 & 29.91 & 0.01 & 19.74 \\
\hline Average & 0.28 & 52.90 & 0.14 & 50.99 & 0.06 & 33.90 \\
\hline
\end{tabular}

Table 5: Monthly average $\mathrm{Pb}$ and TSPM levels.

country's population. There has never been any known study which has statistically linked these pollutants to any health impacts on the population of Zimbabwe, but this is advisable. Therefore, further studies are recommended to ascertain the effect of $\mathrm{SO}_{2}, \mathrm{NO}_{2}$ gases, $\mathrm{Pb}$ and particulate emissions on human health and the environment in Zimbabwean cities

\section{Conclusion}

Air quality in Harare was compromised by the presence of $\mathrm{SO}_{2}$, $\mathrm{NO}_{2}, \mathrm{~Pb}$ and particulate matter. During the sampling period, all these pollutants were found to be above the air quality guidelines provided by $\mathrm{WHO}$, and of much concern were levels of $\mathrm{SO}_{2}$ and particulate matter. Air pollution was found to be higher during winter in the month of July than in the beginning of summer in the month of September. The pollutants were transported by wind and ended up far away from sources of pollution. This was observed mainly for $\mathrm{SO}_{2}$ which ended being a major pollutant in Mufakose, a residential area. The high ambient air concentrations of $\mathrm{SO}_{2}$ and particulate matter were mainly due to vehicles and industrial operations near the sampling sites. $\mathrm{NO}_{2}$ pollution was found to be mainly from vehicles.

\section{References}

1. Zimbabwe census report for 2002, Government Printers, Harare, Zimbabwe.

2. Elmissiry M (2004) Scientific and Industrial Research Development Centre (SIRDC) 2004 Report. SIRDC, Harare, Zimbabwe.

3. Haiding K, Huang W, Chen B, Zhao N (2009) Impact of outdoor air pollution on cardiovascular in Mainland China. CVD Prevention and Control 4: 71-79.

4. Perry R, Young RJ (1977) Handbook of pollution analysis. New York: Chapman and Hall Ltd. Polish Standard PN-89/Z-04092/08; Wydawnictwa Normalizacyjne "Alfa": Warsaw, 1989 (English translation).

5. Strauss W (1978) Air pollution control, Part 3: measuring and monitoring air pollutants. New York: Wiley Interscience.
6. Jonalagadda SB, Nyangani M, Sawunyama P, El-Bussidy AHS (1989) Air pollution monitoring and control. Indian J Enviro Prot 9: 307-311.

7. Jonalagadda SB, Nyangani M, Sawunyama P (1991) Studies on the levels of sulphur dioxide, nitrogen dioxide, ammonia, and hydrogen chloride in ambient air of Harare, Zimbabwe. Environ International 17: 461-467.

8. World Health Organisation (2005) Air quality guidelines for particulate matter, ozone, nitrogen dioxide and sulphur dioxide. Global update, Geneva, Switzerland.

9. Dadvand P, Rankin J, Rushton S, Pless-Mulloli T (2011) Ambient air pollution and congenital heart disease: A register-based study. Environ Res 111: 435441.

10. Holdgate MW (1979) A perspective of environmental pollution. Cambridge University Press, Cambridge 3.

11. Krupa SV, Legge AH (2000) Passive sampling of ambient, gaseous air pollutants: an assessment from an ecological perspective. Environ pollut 107 $31-45$

12. Beamish LA, Osornio-Vargas AR, Wine E (2011) Air pollution: An environmental factor ontributing to intestinal disease. J Crohns Colitis 5: 279-286.

13. Colvill KE, Horsman DC, Roose ML, Roberts TM, Bradshaw AD (1985) Field trials on the influence of air pollutants, and sulfur dioxide in particular, on the growth of ryegrass Lolium perenne. Environ Pollut Series A 39: 235-266.

14. Pande PC, Mansfield TA (1985) Response of winter barley to $\mathrm{SO}_{2}$ and $\mathrm{NO}_{2}$ pollution alone and in combination. Environ pollut Series A 39: 281-291.

15. Fostås B, Gangstad A, Nenseter B, Pedersen S, Sjøvoll M, et al. (2011) Effects of $\mathrm{NO}_{x}$ in the flue gas degradation of MEA. Energy Procedia 4: 1566-1573.

16. Singh SN, Yunus M, Srivasta K, Kulshreshtha K, Ahmad KJ (1985) Response of Calendula officinalis $\mathrm{L}$. to long-term fumigation with $\mathrm{SO}_{2}$. Environ pollut Series A 39: 17-25.

17. Pandey J, Agrawal M (1994) Growth responses of tomato plants to low concentrations of sulphur dioxide and nitrogen dioxide. Sci Hortic 58: 67-76.

18. Cohen A, Anderson HR, Ostro B, Pandey KD, Krzyzanowski M, et al. (2005) The burden of disease due to outdoor air pollution. J Toxicol Environ Health $A$ 68: $1301-1307$. 
Citation: Mujuru M, McCrindle RI, Gurira RC, Zvinowanda CM, Maree J (2012) Air Quality Monitoring in Metropolitan Harare, Zimbabwe. J Environment Analytic Toxicol 2:131. doi:10.4172/2161-0525.1000131

Page 7 of 7

19. HEI International Oversight Committee (2004) Health effects of outdoor air pollution in developing countries of Asia: a literature review. Boston, MA, Health Effects Institute.

20. Goodman JE, Dodge DG, Bailey LA (2010) A framework for assessing casuality and adverse effects of humans with a case study of $\mathrm{SO}_{2}$. Regul Toxicol Pharmacol 58: 308-322.

21. (1954) Her Majesty's Public Health Service Report No. 95.

22. Krochmal D, Gorski L (1991) Determination of nitrogen dioxide in ambient air by use of a passive sampling technique and triethanolamine as absorbent. Environ Sci Technol 25: 531-535.

23. Krochmal D, Kalina A (1997) A method of nitrogen dioxide and sulphur dioxide determination in ambient air by use of passive samplers and ion chromatography. Atmospheric Environment 31: 3473-3479.

24. Kemeny E, Halliday EC (1974) Methods recommended for the measurement of air pollution in South Africa. Council for Scientific and Industrial Research (CSIR) Special Report.

25. Verma SK, Deb MK, Verma D (2008) Determination of $\mathrm{NO}_{2}$ in ambient air employing diffuse reflectance fourier transform infra red. Atm Res 90: 33-40.

26. Markandya A, Halsnaes K (2002) Climate Change and Sustainable Development: Prospects for Developing Countries. Earthscan 215.

27. Cohen A, Anderson HR, Ostro B, Pandey KD, Krzyzanowski M, et al. (2004)
Mortality impacts of urban air pollution. Comparative quantification of health risks: global and regional burden of disease attributable to selected major risk factors. Geneva, World Health Organisation 1353-1434.

28. Hedley AJ, Wong CM, Thach TQ, Ma S, Lam TH, et al. (2002) Cardiorespiratory and all-cause mortality after restrictions on sulfur content in Hong Kong: an intervention study. Lancet 360: 1646-1652.

29. Katsouyani K, Touloumi G, Spix, C, Schwartz J, Balducci F, et al. (1997) Short term effects of ambient sulphur dioxide and particulate matter on mortality in 12 European cities: results from time series data from APHEA project. Br Med J 314: 1658-1663.

30. Dockey DW, Pope CA, Xu X, Spengler JD, Ware JH, et al. (1993) An association between air pollution and mortality in six US cities. N Engl J Med 329: 1753-1759.

31. Abas MRB, Mohamad S (2011) Hazardous (Organic) Air Pollutants. Encyclopedia Environ Health 23-33.

32. Schwartz J (2001) Air pollution and blood markers of cardiovascular risk Environ Health Perspect 109: 405-409.

33. Callén MS, de la Cruz MT, López JM, Mastral AM (2011) PAH in airborne particulate matter: Carcinogenic character of PM10 samples and assessment of the energy generation impact Original Research Article. Fuel Proces Techno 92: $176-182$.

34. Schwartz J (1999) Air pollution and hospital admissions for heart disease in eight U.S. counties. Epidemiology 10: 17-22. 